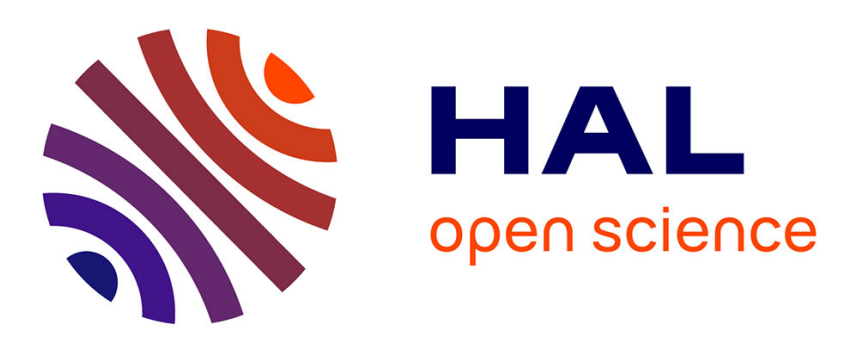

\title{
Behavioral responses underpinning resistance and susceptibility of honeybees to Tropilaelaps mercedesae
}

Kitiphong Khongphinitbunjong, Lilia Guzman, Michael Burgett, Thomas

Rinderer, Panuwan Chantawannakul

\section{To cite this version:}

Kitiphong Khongphinitbunjong, Lilia Guzman, Michael Burgett, Thomas Rinderer, Panuwan Chantawannakul. Behavioral responses underpinning resistance and susceptibility of honeybees to Tropilaelaps mercedesae. Apidologie, 2012, 43 (5), pp.590-599. 10.1007/s13592-012-0129-x . hal01003651

\section{HAL Id: hal-01003651 \\ https://hal.science/hal-01003651}

Submitted on 1 Jan 2012

HAL is a multi-disciplinary open access archive for the deposit and dissemination of scientific research documents, whether they are published or not. The documents may come from teaching and research institutions in France or abroad, or from public or private research centers.
L'archive ouverte pluridisciplinaire HAL, est destinée au dépôt et à la diffusion de documents scientifiques de niveau recherche, publiés ou non, émanant des établissements d'enseignement et de recherche français ou étrangers, des laboratoires publics ou privés. 


\title{
Behavioral responses underpinning resistance and susceptibility of honeybees to Tropilaelaps mercedesae
}

\author{
Kitiphong Khongrhinitbunjong ${ }^{1}$, Lilia I. de Guzman ${ }^{2}$, Michael D. BurgetT ${ }^{3}$, \\ Thomas E. Rinderer ${ }^{2}$, Panuwan CHANTAWANNAKUL ${ }^{1,4}$ \\ ${ }^{1}$ Bee Protection Center, Department of Biology, Faculty of Science, Chiang Mai University, Chiang Mai 50200, \\ Thailand \\ ${ }^{2}$ USDA/ARS, Honey Bee Breeding, Genetics and Physiology Laboratory, 1157 Ben Hur Road, Baton Rouge, LA \\ 70820, USA \\ ${ }^{3}$ Department of Horticulture, Oregon State University, Corvallis, OR 97331, USA \\ ${ }^{4}$ Materials Science Research Center, Faculty of Science, Chiang Mai University, Chiang Mai, Thailand
}

Received 17 June 2011 - Revised 11 January 2012 - Accepted 7 February 2012

\begin{abstract}
Behavioral responses of Apis cerana, Apis dorsata, and Apis mellifera to the ectoparasitic mite, Tropilaelaps mercedesae, were compared using two laboratory bioassays: cohorts of 50 caged worker bees and individual-caged worker bees, all of unknown ages. For the group bioassays, ten T. mercedesae were placed on the bodies of bees in each cohort. After $6 \mathrm{~h}$, nearly $2 / 3$ of the mites placed on $A$. cerana had fallen from the bees onto sticky traps that were placed under the cages, compared to only about $1 / 3$ for $A$. dorsata and $A$. mellifera. The majority of fallen mites fell within $24 \mathrm{~h}$ from $A$. cerana $(93.3 \pm 2.3 \%), 36 \mathrm{~h}$ from $A$. dorsata $(92.2 \pm$ $1.9 \%)$, and $48 \mathrm{~h}$ from $A$. mellifera $(91.3 \pm 1.4 \%)$. Higher proportions of injured mites were observed among the mites that fell from $A$. cerana $(38.3 \pm 12.9 \%)$ and $A$. dorsata $(33.9 \pm 17.4 \%)$ than among those that fell from $A$. mellifera $(19.5 \pm 7.2 \%)$. The rapid fall of mites from the bodies of $A$. cerana may be due to a combination of autogrooming and rapid body shaking of the bees. In individual bee assays, where individual bees were challenged with one female $T$. mercedesae, A. cerana and $A$. dorsata exhibited faster behavioral responses to the presence of mites than did A. mellifera $(39.4 \pm 13.2,44.9 \pm 19.2$, and $188.4 \pm 63.9 \mathrm{~s}$, respectively). Phoretic $T$. mercedesae were mostly observed attaching to the propodeum/petiole region of all three bee species, although some mites also occupied the wing base area of $A$. dorsata and A. mellifera.
\end{abstract}

grooming behavior / Apis cerana / Apis dorsata / Apis mellifera / Tropilaelaps mercedesae

\section{INTRODUCTION}

Mites, in the genus Tropilaelaps, are primary brood ectoparasites of the giant Asian honeybees (Apis dorsata and Apis laboriosa) (Delfinado-Baker et al. 1989), although they are not considered to be serious pests of these bee species. This is primarily due to their inability to feed on adult bees (Koeniger and

Corresponding author: P. Chantawannakul, panuwan@gmail.com

Manuscript editor: Peter Rosenkranz
Musaffar 1988). Hence, the mites can only survive in colonies with the presence of brood in which they readily feed and reproduce while inside the cells. In vitro studies have shown that Tropilaelaps mercedesae (previously mistaken for Tropilaelaps clareae) lives only ca. 1-3 days on adult bees (Kitprasert 1984; Woyke 1984; Koeniger and Musaffar 1988; Rinderer et al. 1994). In addition, natural migrations of giant honeybees produce long broodless periods, which reduce mite infestation rates (Wongsiri et al. 1989). Brood nest hygienic behavior and other behaviors such as shimmering (Butler 
1954) or body shaking (Sakagami 1960) have also been shown to severely reduce Tropilaelaps populations in $A$. dorsata colonies (Burgett et al. 1990). It is also likely that there are other behavioral mechanisms of resistance to Tropilaelaps in giant honeybees which have yet to be identified.

Tropilaelaps spp. infest Apis mellifera imported to Asia with devastating effect. Earlier reports identified $T$. clareae to be the most serious parasite of $A$. mellifera colonies in Asia (Burgett et al. 1983). However, with the identification of new Tropilaelaps species, $T$. mercedesae is now known to be the most widely spread Tropilaelaps species causing mortality of $A$. mellifera colonies (Anderson and Morgan 2007). T. mercedesae infestation of $A$. mellifera occurs in regions well outside the distribution of giant honeybees, and hence, the mite is regarded as an emerging global threat to this bee species (Anderson and Morgan 2007). The once considered most serious threat to $A$. mellifera, $T$. clareae, is now known to only cause losses of $A$. mellifera colonies in the Philippines (Cervancia 1993), while the remaining two species in the genus, Tropilaelaps koenigerum and Tropilaelaps thaii, are considered harmless to A. mellifera (Anderson and Morgan 2007).

In Asia, Tropilaelaps spp. have also been collected from colonies of Apis cerana and Apis florea. Individuals of $T$. mercedesae (which at the time was thought to be $T$. clareae) have been found in A. cerana colonies in Pakistan, Myanmar, and Thailand (Delfinado-Baker 1982; Wongsiri et al. 1989) and, in India, associated with adult bees of $A$. florea (Kapil and Aggarwal 1987). Nevertheless, T. koenigerum has been found reproducing on the brood of A. cerana in India (Abrol and Putatunda 1995 ) and, recently, one adult female T. mercedesae was found reproducing on A. cerana brood in Thailand (Anderson and Morgan 2007). Although these latter observations span a wide geographical range, Tropilaelaps is only rarely found on A. cerana and normally those infestations are not associated with mite reproduction.
The low incidence of $T$. mercedesae infestations in A. cerana colonies in locations that are cohabited with giant honeybees suggests that these honeybees have a strong resistance to this parasite. However, no explanation of the resistance mechanism has been offered. It is possible that behavioral mechanisms underpin the resistance of $A$. cerana to $T$. mercedesae. The objectives of this study were to determine the mite removal time of $T$. mercedesae on worker bees of three honeybee species (A. cerana, $A$. dorsata, and $A$. mellifera), and to determine if behavioral responses mediate their resistance to T. mercedesae.

\section{MATERIALS AND METHODS}

\subsection{Source and genotypic identification of Tropilaelaps mites}

Tropilaelaps mites used in our studies were obtained from sealed brood of A. mellifera in an apiary located at the Bee Protection Center, Chiang Mai University, Chiang Mai, Thailand. Their identity was confirmed by DNA analysis. For this, genomic DNA was extracted from each of ten mites as described by Boonham et al. (2002). The entire ITS1-5.8S-ITS2 gene region was amplified using an ITS4 primer (5'-TCCTCCGCTTATTGATATGC-3') and an ITS5 primer (5'-GGAAGTAAAAGTCG TAACAAGG-3') in a GeneAmp ${ }^{\circledR}$ PCR System 9700 thermal cycler (Applied Biosystems, USA) (White et al. 1990). The mixture was initially denatured at $94^{\circ} \mathrm{C}$ for $4 \mathrm{~min}$ and then processed with 30 amplification cycles, each consisting of $1 \mathrm{~min}$ at $94^{\circ} \mathrm{C}, 1 \mathrm{~min}$ at $56^{\circ} \mathrm{C}$, and $1 \mathrm{~min}$ at $72^{\circ} \mathrm{C}$. The reactions were completed by a final extension step for $10 \mathrm{~min}$ at $72^{\circ} \mathrm{C}$. This step was modified from the methods of Anderson and Morgan (2007). The PCR products were separated on a $1.5 \%$ agarose gel by electrophoresis. PCR bands were purified by using NucleoSpin ${ }^{\circledR}$ Exact II (Germany). When compared in the GenBank database using the BioEdit program (Hall 1999), the DNA sequences (320-520 bp) derived from our samples (accession number HM748312-HM748316) showed a 99\% similarity to sequences from $T$. mercedesae collected from Sri 
Lanka (EF025472.1) and Palawan, Philippines (EF025471.1) and hence were confirmed as $T$. mercedesae (Anderson and Morgan 2007).

\subsection{Experiment 1. Evaluation of the responses to $T$. mercedesae using groups of caged bees}

The cages used to house bees in this experiment were plastic containers $(18 \times 8 \times 4 \mathrm{~cm})$, each with a single hole $($ diameter $=1.3 \mathrm{~cm})$ on the top covered with a screen mesh $(8$ mesh) and with the entire bottom removed and replaced with mesh that prevented bees from escaping but allowed mites to pass through. This mesh also served as ventilation for the bees. A sheet of cardboard, coated with a mixture of petroleum jelly and vegetable oil (1:1), was attached to the bottom of each cage under the screen mesh to trap mites that fell from the caged bees.

We compared the responses of A. cerana, $A$. dorsata, and $A$. mellifera to $T$. mercedesae that were introduced into the cages. A total of 11 colonies (three $A$. cerana, three $A$. dorsata, and five $A$. mellifera) were used as sources for the test bees. From all of the five $A$. mellifera and two of the $A$. cerana colonies, 50 worker bees of unknown ages were randomly collected from the brood nest of their parent colonies. Additionally, worker bees from the entrance of one feral colony of $A$. cerana were used. The $A$. mellifera colonies used as a source for the test bees were different from the colonies used as the source for mites. A. dorsata worker bees were collected from three different colonies in the provinces of Phayao and Chiang Mai by scooping bees from the curtain of each nest using an insect net. In order to facilitate introduction of bees into the cages, all test bees (all three species) were anesthetized with carbon dioxide.

For each of the 11 honeybee colonies, 6 cages (each cage represented one replicate) were established for a total of 66 cages (A. cerana $=18, A$. dorsata $=18$, and A. mellifera=30). Each cage received ten adult female Tropilaelaps of unknown age. To increase the possibility that all inoculum mites were females, mites were collected from newly sealed bee larvae to white-eyed pupae. Using a fine brush (size, number 0), the collected mites were transferred into a Petri dish with bee pupae until enough mites $(\geq 10)$ were collected to inoculate one cage of bees. Individual mites were then introduced through the cage hole onto bees using the brush. The cages were then placed inside an incubator at $30^{\circ} \mathrm{C}$ and $40 \%$ relative humidity. The number of mites that fell to the sticky trap attached to the bottom of the cages was monitored at $6,12 \mathrm{~h}$, and then every $12 \mathrm{~h}$ until no additional mites fell. All fallen mites were collected and immediately examined under a dissecting microscope for the presence or absence of injuries. Sex of the mites was also confirmed at this time. Following 24-48 h, when no further fallen mites were observed, each cage was placed in a plastic bag and frozen to kill the bees and any remaining mites. Bees were then washed with water to recover phoretic mites left on the bees in order to validate grooming efficiency. The plastic bags were also inspected for the presence of mites. After washing, individual bees were further examined visually under a microscope to ensure that no mites remained. Observations were made during the period February to April 2010.

Behavioral responses of caged honeybees toward the introduced Tropilaelaps were observed using the "scan sampling" technique (Martin and Bateson 2007) for each observation period. In brief, cages of bees were scanned for ca. 3 min for the occurrence of grooming behavioral activities by using a video camera (Sanyo VPC-TH1, Vietnam) set up $5 \mathrm{~cm}$ from the side of the cage. Eight observations for A. cerana, 3 for A. dorsata, and 16 for $A$. mellifera were recorded. Visual observation on the response of bees was also made during mite inoculation.

In order to verify whether or not body shaking in A. cerana was triggered by the presence of Tropilaelaps or the presence of an "observer" while recording, two groups of $A$. cerana (three colonies used as sources of test bees) were established: miteinoculated (five cages) and not mite-inoculated (five cages) as the control. Bees' responses to the mites were recorded after 6,12 , and $24 \mathrm{~h}$ post-inoculation for ca. $5 \mathrm{~min}$. Mites that fell were also collected and examined for injuries under a dissecting microscope. All bees were washed with water and also examined individually after $24 \mathrm{~h}$ for the presence or absence of phoretic mites. Control cages were also recorded to determine if the presence of an observer elicited body shaking behavior. 


\subsection{Experiment 2. Individual bee responses toward $T$. mercedesae and attachment sites of the mites}

Worker bees from a single colony of $A$. cerana, and A. mellifera (both used in experiment 1) were collected in front of the hive entrances using an insect net. Since the $A$. dorsata colony used in experiment 1 absconded, A. dorsata worker bees were collected from a new nest with the aid of an insect net. Bees of each species were placed in separate holding cages (described in Section 2.2) and fed honey prior to being exposed to T. mercedesae. For each species, 20 bees were randomly selected and placed individually into small Petri dishes (diameter $=50 \mathrm{~mm}$ ). Ten bees were individually inoculated with one mite each using a fine brush, while the other ten bees served as controls (touched with the brush without mite inoculation). Female Tropilaelaps were collected from either emerging brood or tan-bodied pupae of one highly infested A. mellifera colony, different from the one used to source A. mellifera test bees. Behavioral responses of both groups toward the introduced Tropilaelaps were recorded simultaneously for $10 \mathrm{~min}$ using two video cameras (Sanyo VPC-TH1, Vietnam and Panasonic HDC-HS250, Japan).

After mite inoculation, grooming activities (related or unrelated to the presence of mite) were observed and counted within a 10 -min period. Latency or time from mite introduction to either the onset of the first occurrence of grooming activity or mite drop (which probably reflects undetected grooming) was also measured (Martin and Bateson 2007). Successful removal of a mite was defined as the ability of the bee to rid itself of the mite (regardless of the mite remounting the bee) within the 10-min period. All mites that fell from the bee were examined under a dissecting microscope for the presence or absence of injuries. Observations on the attachment sites of the inoculated mites on the bees were also noted microscopically and visually during this time. At the end of each observation, each bee was examined under a dissecting microscope to determine the final attachment site of the inoculated mite.

\subsection{Data analyses}

Data on the cumulative proportion of mites that dropped from bees through time were first trans- formed using an arcsine-square root transformation to approximate normality and then subjected to analysis of variance (ANOVA) for repeated measures by using PROC MIXED (SAS version 9.2, SAS Institute 2008). Since a significant interaction between honeybee species and time of observation was detected, a post hoc slice test was performed to determine the effect of honeybee species on the proportion of mites that had fallen during each observational period. The effect of honeybee species on the proportion of injured mites (calculated as the number of injured mites divided by total mites that fell) was determined using a one-factor ANOVA. The proportions of injured mites were transformed using an arcsine-square root. Data on grooming activities approximated normality, so data were not transformed. A two-factor ANOVA was used to determine the effects of honeybee species and the presence or absence (brush-touched only) of T. mercedesae on their occurrence. There was no interaction detected; thus, no posttest was necessary. Grooming response time was transformed using a square root transformation to approximate normality. To determine the effect of honeybee species on the grooming response time toward an introduced mite, a one-factor ANOVA was used. Means were separated with Bonferroniadjusted $t$ tests.

\section{RESULTS}

\subsection{Experiment 1. Evaluation of the responses of three honeybees to $T$. mercedesae using groups of caged worker bees}

\subsubsection{Cumulative proportion of fallen T. mercedesae}

Analysis of the number of $T$. mercedesae that fell to the cage floors showed a significant interaction between honeybee species and time of observation $(F=16.38 ; d f=10,378 ; P<$ $0.0001)$. Almost $2 / 3$ of the inoculated mites had fallen from the caged A. cerana after $6 \mathrm{~h}$ (Table I). In contrast, only about $1 / 3$ of the mites fell from the caged $A$. dorsata and $A$. mellifera during the same time period. A similar 
Table I. Cumulative proportion (mean $\pm \mathrm{SE}$ ) of $T$. mercedesae that fell from cages of three different honeybee species through time and condition of fallen mites.

\begin{tabular}{lccc}
\hline \multicolumn{2}{c}{$\begin{array}{c}\text { Apis cerana } n=18 \text { cages; } \\
180 \text { mites }\end{array}$} & $\begin{array}{l}\text { Apis dorsata } n=18 \text { cages; } \\
180 \text { mites }\end{array}$ & $\begin{array}{l}\text { Apis mellifera } n=30 \text { cages; } \\
300 \text { mites }\end{array}$ \\
\hline $\begin{array}{l}\text { Time of observation }(\mathrm{h}) \\
6\end{array}$ & $61.1 \pm 1.6 \mathrm{a}$ & $38.9 \pm 4.5 \mathrm{~b}$ & $34.0 \pm 2.2 \mathrm{~b}$ \\
12 & $82.2 \pm 2.4 \mathrm{a}$ & $63.9 \pm 2.8 \mathrm{~b}$ & $52.3 \pm 1.8 \mathrm{~b}$ \\
24 & $93.3 \pm 2.3 \mathrm{a}$ & $87.2 \pm 1.4 \mathrm{a}$ & $66.0 \pm 1.9 \mathrm{~b}$ \\
36 & - & $92.2 \pm 1.9 \mathrm{a}$ & $82.0 \pm 1.5 \mathrm{~b}$ \\
48 & - & - & $91.3 \pm 1.4$ \\
Condition of mites & & & $80.4 \pm 1.3 \mathrm{a}$ \\
Uninjured & $61.7 \pm 4.1 \mathrm{~b}$ & $65.9 \pm 3.0 \mathrm{~b}$ & $19.5 \pm 7.2 \mathrm{~b}$ \\
Injured & $38.3 \pm 12.9 \mathrm{a}$ & $33.9 \pm 17.4 \mathrm{a}$ & \\
\hline
\end{tabular}

For each time of observation and mite condition, means for the different honeybee species followed by different letters are significantly different at $P<0.05$.

trend was observed after $12 \mathrm{~h}$ of observation. After $24 \mathrm{~h}$, similarly high proportions of mites fell from caged $A$. cerana and $A$. dorsata workers, compared with low proportions from the caged $A$. mellifera. No fallen mites were recorded from A. cerana after $36 \mathrm{~h}$. At this time, a higher proportion of mites had fallen from the caged $A$. dorsata than fell from caged $A$. mellifera ( $t=3.81, P=0.0002)$. Overall, it took only $24 \mathrm{~h}$ before most mites $(>90 \%)$ had fallen from caged $A$. cerana, and this was 12 and $24 \mathrm{~h}$ faster than for $A$. dorsata and A. mellifera, respectively. At the end of the experiment, a similar proportion of mites was not recovered for all honeybee species (Tukey's test, $P>0.05$ ) (A. cerana $=6.7 \pm 0.9 \%$, A. dorsata $=7.8 \pm 0.8 \%$, and $A$. mellifera $=7.7 \pm 0.7 \%$ ). No mites were recovered from the bee washes or inspections of individual bees. A similar trend was observed in the mite-inoculated vs. not mite-inoculated assay wherein $56 \pm 8 \%$ of the mites had fallen within $6 \mathrm{~h}, 84 \pm 10 \%$ within $12 \mathrm{~h}$, and $92 \pm 7.5 \%$ within $24 \mathrm{~h}$.

\subsubsection{Injury to phoretic T. mercedesae}

Inspections of the phoretic mites that fell showed that most were apparently uninjured for all three honeybee species. However, the num- ber of injured mites was influenced by honeybee species $(F=15.61 ; d f=2,63 ; P<0.0001)$. The proportion of injured Tropilaelaps that fell from caged $A$. cerana was similar to that of $A$. dorsata yet significantly higher than for caged A. mellifera (Table I). Regardless of the time of observation and mites' condition (injured or not), all mites collected were dead. Results of the mite-inoculated vs. not mite-inoculated assay also showed similar trends (uninjured= $60.7 \pm 7.5 \%$, injured $=39.3 \pm 4 \%$ ).

Injuries observed on fallen mites were located on different parts of the mites' body (Table II), with the majority of damage occurring on the legs. The palpus and body shield showed the least damage.

\subsubsection{Description of the behavioral responses of three honeybee species to introduced T. mercedesae}

We report patterns of behavioral responses of bees (infested or not) based on examining 8, 3, and 16 video recordings for $A$. cerana, $A$. dorsata, and $A$. mellifera, respectively. A behavior common to all three honeybee species was auto-grooming. The grooming bees raised their abdomens slightly and brushed their abdomens with their hind legs, or rubbed their hind 
Table II. Percentage of total injuries inflicted on T. mercedesae by three honeybee species.

\begin{tabular}{lcccccc}
\hline Honeybee species & \multicolumn{6}{l}{ Body part } \\
\cline { 2 - 7 } & Leg 1 & Leg 2 & Leg 3 & Leg 4 & Palp & Body shield \\
\hline A. mellifera & 47.1 & 25.0 & 17.6 & 5.9 & 1.5 & 2.9 \\
A. dorsata & 33.0 & 20.5 & 10.2 & 30.7 & 4.5 & 1.1 \\
A. cerana & 50.0 & 16.7 & 15.3 & 11.1 & 4.2 & 2.8 \\
\hline
\end{tabular}

legs together. Most of the time, the bees twisted or pivoted their abdomens while grooming. The bees also used both fore- and mid legs to groom the head and thorax. While auto-grooming, $A$. cerana, unlike $A$. mellifera or $A$. dorsata, also engaged in "body shaking". For this, the $A$. cerana workers moved their bodies rapidly in a side-to-side movement $(10.47 \pm 1.41 \mathrm{~Hz}, n=10)$. During this body shaking, the bees shook their bodies repetitively.

Groups of $A$. cerana inoculated with $T$. mercedesae and those that were not inoculated with mites also displayed common autogrooming activities described above. However, body shaking was observed in 6 out of 11 video recordings. In the control group, no body shaking was observed at any of the observation times $(6,12$, or $24 \mathrm{~h} ; n=10$ videos). We also observed $A$. cerana (two out of eight recordings) and $A$. mellifera ( 3 out of 16 recordings) displaying allo-grooming against $T$. mercedesae. No allo-grooming was observed with $A$. dorsata. A. mellifera was the only honeybee species that displayed "Nasanov-scenting" behavior which was observed in 7 out of the 16 video recordings analyzed.

\subsection{Experiment 2. Evaluation of the responses of three honeybee species to $T$. mercedesae using individual worker bees}

\subsubsection{Latency to the onset of grooming activities by three honeybee species}

Analysis showed that when individual bees were presented with $T$. mercedesae, the latency, or time from mite introduction to either the onset of the first of grooming activity or mite drop, varied among species of honeybees $(F=$

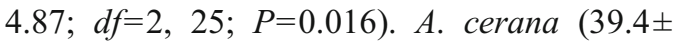
$13.2 \mathrm{~s})$ and $A$. dorsata $(44.9 \pm 19.2 \mathrm{~s})$ responded to the presence of $T$. mercedesae more quickly than did the A. mellifera (188.4 $\pm 63.9 \mathrm{~s})$.

\subsubsection{Behavioral responses and attachment sites}

The auto-grooming activities described in Section 3.1.3 using groups of caged worker bees were also observed in the single-bee bioassay. There were no apparent differences in the details of the grooming responses of the three honeybee species. However, we observed a significant $(F=$ 10.38; $d f=2,54 ; P=0.0002)$ interaction between honeybee species and treatment (mite vs. being touched with a brush; Fig. 1) for the number of grooming activities performed. When presented with a mite, $A$. dorsata and $A$. cerana equally groomed more than did $A$. mellifera. But when touched with a brush, A. mellifera displayed more grooming activities than $A$. cerana and $A$. dorsata, even with the absence of a mite threat. However, we did not observe any body shaking using individual $A$. cerana worker bees. Similarly, no Nasanov scenting was observed in A. mellifera.

T. mercedesae used several attachment sites on all the three honeybee species. The majority of the phoretic mites moved constantly from one site to another as the infested bees groomed. The mites were either around the head/headthorax region, on the scutellum with their opisthosoma protruding, on the dorsal or lateral 


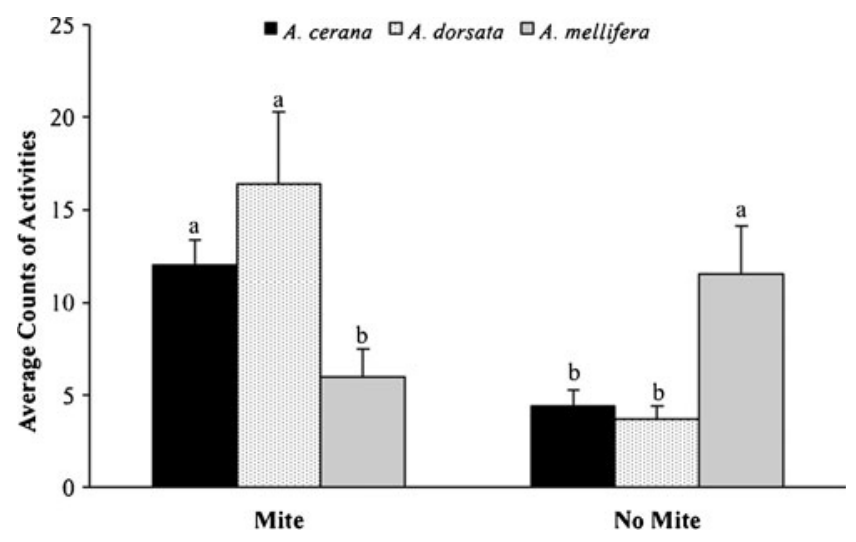

Figure 1. Number (mean $\pm \mathrm{SE}$ ) of grooming activities as affected by honeybee species within a 10-min observation period. For each inoculation type, bars with different letters are significantly different at $P<0.05$.

side of thorax attached to a cluster of setae, near the wing base, between the base of forelegs (ventral) with opisthosoma protruding, near the base of a leg, femur of the leg, or between the thorax and abdomen (propodeal tergite) with the head pointing toward the petiole or on the concave dorsum of the abdomen. However, at the end of the experiment, about $61.5 \%$ and $50 \%$ of the mites were found in the petiole region of $A$. cerana and A.mellifera, respectively. On $A$. dorsata, the mites were found at several attachment sites, but more mites were found near the base of the wings $(28.6 \%)$ and petiole region $(28.6 \%)$.

\section{DISCUSSION}

Our results showed substantial differences in the survival of $T$. mercedesae when artificially placed on $A$. cerana, A. dorsata, and $A$. mellifera worker bees, which was probably related to worker bee grooming behavior. The shortest survival was observed on $A$. cerana (24 h). Mite survival on $A$. dorsata, which is the indigenous host of Tropilaelaps, was longer (36 h), while mites survived longest on $A$. mellifera (48 h). In Pakistan, Koeniger and Musaffar (1988) reported a similar survival $(27 \mathrm{~h})$ of $T$. clareae (which was most likely $T$. mercedesae, as T. clareae has been shown to be restricted to the Philippines) on A. cerana. However, they found that survival was shortest on A. mellifera $(25 \mathrm{~h})$ and longest on $A$. dorsata (57 h), which contrasts sharply with our results. This discrepancy may be due to the differences in the genotypes of the three species of honeybees studied. Radloff et al. (2010) documented that $A$. cerana from Pakistan belongs to the morphocluster Northern cerana, while $A$. cerana of Northern Thailand is of the Indochinese cerana type. Differences in the methodology used may have also contributed to this disparity. In this study, we used 50 bees per cage and kept them in a $30^{\circ} \mathrm{C}$ incubator, while Koeniger and Musaffar (1988) used 20 bees per cage kept at $26^{\circ} \mathrm{C}$. The number of bees per cage and temperature may have had a significant effect on the bees' ability to groom.

So far, reproduction of $T$. mercedesae has only been observed in one capped brood cell of A. cerana (Anderson and Morgan 2007). This rare observation may be due to the bees' resistance to this brood parasite, which may also explain their poor survival on adult bees in this study. The poor survival of T. mercedesae on A. cerana may be due to a suite of defense strategies displayed by this honeybee species. For example, in our studies $A$. cerana performed apparently intense and long autogrooming episodes when exposed to $T$. mercedesae. In addition, A. cerana performed body 
shaking (with an intensity that should suffice to dislodge phoretic mites), which is normally displayed by guard bees as a defense mechanism to bee-hawking by Vespa velutina (Tan et al. 2005; Tan et al. 2010). Body shaking has also been observed in Apis nuluensis (Koeniger et al. 1996) and A. dorsata (Kastberger et al. 1998) against Vespa spp. and other predators. It is unlikely that the body shaking observed in our experiments was triggered by the presence of an "observer" while recording since no body shaking was observed in either the uninoculated cages (group bioassay) or the single-bee bioassay (mite-inoculated and brush-touched only) in which one to two observers were present. Since we also did not observe body shaking in any of the mite-inoculated individual A. cerana, this observation suggests the importance of body shaking as a "signal or warning" of the presence of intruders in a social setting. However, groups of $A$. dorsata worker bees did not respond similarly to the presence of $T$. mercedesae in this study, although they are known to engage in the behavior in a different context. We were not able to confirm whether a bee that displayed body shaking was infested with Tropilaelaps. They may not all have been infested since not all of them displayed intermittent autogrooming. Perhaps body shaking may also be a response to the actions of infested bees nearby. The body shaking and wing activation of infested bees may have produced a sound or vibration that triggered other bees to also engage in these actions. This hypothesis may explain our observations of the simultaneous body shaking of bees which were not in direct contact.

Similarly, while we observed Nasanov scenting [a behavior observed in A. nuluensis (Koeniger et al. 1996) and in A. dorsata against predatory wasps (Kastberger et al. 1998)] in $A$. mellifera workers caged in groups, no Nasanov scenting was observed in the experiment using single bees. Thus, it is also possible that this behavior is only expressed in a group setting. Whether or not this behavior was performed in response to the presence of mites is unclear with our available data.
Tropilaelaps have a different body structure from that of Varroa mites which prevents them from concealing themselves between the sternites of the bees (Rath 1999). In this study, we observed different attachment sites for T. mercedesae while being phoretic on adult bees. However, the propodeum/petiole region (concave area of the dorsal abdomen) seemed to provide the most protection for the mite especially in $A$. cerana and $A$. mellifera. Similar observations were reported by Woyke (1984) and Ritter and Schneider-Ritter (1988) for A. mellifera. Although the mites infesting $A$. dorsata also used the petiole region, a similar proportion of them were found near the base of the wings at the end of the experiment. A body action (twisting of the abdomen while a mite is attached at the propodeal tergite of the thorax) may have caused mites to be irritated and move to the more exposed wing base area. The mites in this area moved around as the bees performed autogrooming movements and appeared to be vulnerable to grooming.

Clearly, fallen mites result from a variety of causes. The mites may be brushed off during auto-grooming. Body shaking and wing beating may throw them from the bees. Body twisting may expose them to other grooming actions. Despite having a small sample size, the results of our single-bee experiment showed successful mite removal by $A$. cerana and $A$. dorsata only: four out of ten mites with $A$. cerana (one injured, one without obvious physical injury but not able to walk, and two uninjured and able to walk), and three out of ten with $A$. dorsata (one with injured legs and two uninjured). One successful mite removal in $A$. dorsata was caused by the beating of the wings. In contrast to the findings of Peng et al. (1987) and Büchler et al. (1992) with Varroa jacobsoni, allogrooming did not significantly contribute to the resistance of $A$. cerana to $T$. mercedesae.

In our study, about $1 / 3$ of the fallen mites were injured in both $A$. cerana and $A$. dorsata trials and only about $1 / 5$ in $A$. mellifera trials. Higher proportions of uninjured than injured mites had also been reported by several researchers who studied grooming behavior in 
Varroa mites (Peng et al. 1987; Büchler et al. 1992; Aumeier 2001). With Varroa mites, a high proportion (ranging from $30 \%$ to $50 \%$ ) of groomed mites had damaged legs (Ruttner and Hanel 1992; Rosenkranz et al. 1997; CorrêaMarques et al. 2002), and injuries to the idiosoma were relatively rare (about 1-2\%) (Ruttner and Hanel 1992). Our observations on the types of injuries agreed with these findings.

Our results suggest that the three species of honeybees in the study had varied degrees of behavioral resistance to Tropilaelaps in the phoretic stage. A. cerana appeared to have the highest behavioral resistance owing to its body shaking in response to the presence of mites. Body shaking may be an effective response to Varroa which serves as a preadaptation and is still more effective against Tropilaelaps owing to its morphology. Tropilaelaps has a different morphology from that of Varroa and has probably not coevolved with the behavior. A. dorsata, the natural host of Tropilaelaps, also showed a high level of behavioral resistance to Tropilaelaps. However, since the mite has coevolved with $A$. dorsata, it is more successful on $A$. dorsata than it is on A. cerana. Although $A$. mellifera has not been exposed to parasitic brood mites until its introduction to Asia, it does display auto-grooming behavior in response to them. This is probably a preadaptation as a result of its coevolution with Acarapis mites. The success of $A$. mellifera auto-grooming is less than that of the two Asian bees. However, because A. mellifera was able to remove about $50 \%$ of the mites after $12 \mathrm{~h}$ and injured at least $1 / 5$ of the recovered mites, a selection program may result in a stock of $A$. mellifera that is resistant to $T$. mercedesae. A. mellifera varies in its resistance to Acarapis woodi with European A. mellifera having more resistance than North American $A$. mellifera (de Guzman et al. 1998; de Guzman et al. 2002). Lineages of $A$. mellifera that show increased resistance to $A$. woodi may be more resistant to Tropilaelaps.

\section{ACKNOWLEDGMENT}

We acknowledge the Royal Golden Jubilee Ph.D. Program for the financial support to Kitiphong
Khongphinitbunjong and the Thailand Research Fund. Our appreciation is extended to Amanda Frake who provided statistical help. We thank Dr. Manas Titayawan, staff at School of Agriculture and Natural Resources, Naresuan University, Phayao Campus and Bongkotch Boopha for their assistance in collecting bees. We are also grateful to Dr. Prachaval Sukumalanand (Department of Entomology, Chiang Mai University) for the use of his facility.

Réponses comportementales à la base d'une résistance et d'une susceptibilité des abeilles à Tropilaelaps mercedesae

Comportement de toilettage / Apis cerana / Apis dorsata / Apis mellifera / Acari

Verhaltensreaktionen im Zusammenhang mit einer Resistenz bzw. Anfälligkeit von Honigbienen gegenüber T. mercedesae

Grooming Verhalten / Apis cerana / Apis dorsata / Apis mellifera / Acari

\section{REFERENCES}

Abrol, D.P., Putatunda, B.N. (1995) Discovery of an ectoparasitic mite Tropilaelaps koenigerum Delifinado-Baker and Baker (Acari-Laelapidae) on Apis dorsata, A. meliffera L. and Apis cerana F. in Jammu and Kashmir, India. Curr. Sci. 68, 90

Anderson, D.L., Morgan, M.J. (2007) Genetic and morphological variation of bee-parasitic Tropilaelaps mites (Acari: Laelapidae): new and re-defined species. Exp. Appl. Acarol. 43, 1-24

Aumeier, P. (2001) Bioassay for grooming effectiveness towards Varroa destructor mites in Africanized and Carniolan honeybees. Apidologie 32, 81-90

Boonham, N., Smith, P., Walsh, K., Tame, J., Morris, J., Spence, N., Benison, J., Barker, I. (2002) The detection of Tomato spotted wilt virus (TSWV) in individual thrips vectors using real time Xuorescent RTPCR (Taqman). J. Virol. Methods 101, 37-48

Büchler, R., Drescher, W., Tornier, I. (1992) Grooming behaviour of Apis cerana, Apis mellifera and Apis dorsata and its effects on the parasitic mites Varroa jacobsoni and Tropilaelaps clareae. Exp. Appl. Acarol. 16, 313-319

Burgett, D.M., Akratanakul, P., Morse, R. (1983) Tropilaelaps clareae: A parasite of honeybees in south-east Asia. Bee World 64, 25-28 
Burgett, D.M., Rossignol, P.A., Kitprasert, C. (1990) A model of dispersion and regulation of the brood mite parasite, Tropilaelaps clareae by its giant honeybee host, Apis dorsata. Can. J. Zool. 68, 1423-1427

Butler, C.G. (1954) The World of the Honeybee. Collins, London

Cervancia C. (1993) Philippines Beekeeping: Status of research and development. pp. 49-63. In: Proc. Beenet Asia. Workshop on Priorities in R\&D on Beekeeping in Tropical Asia. 149 pp.

Corrêa-Marques, M.H., De Jong, D., Rosenkranz, P., Gonçalves, L.S. (2002) Varroa-tolerant Italian honeybees introduced from Brazil were not more efficient in defending themselves against the mite Varroa destructor than Carniolan bees in Germany. Genet. Mol. Res. 1, 153-158

de Guzman, L.I., Rinderer, T.E., Delatte, G.T. (1998) Comparative resistance of four honeybee (Hymenoptera: Apidae) stocks to infestation by Acarapis woodi (Acari: Tarsonemidae). J. Econ. Entomol. 91, 1078-1083

de Guzman, L.I., Rinderer, T.E., Delatte, G.T., Stelzer, J. A., Beaman, G., Kuznetsov, V. (2002) Resistance to Acarapis woodi by honeybees from Far-eastern Russia. Apidologie 33, 411-415

Delfinado-Baker, M. (1982) New records for Tropilaelaps clareae from colonies of Apis cerana indica. Am. Bee J. 122, 382

Delfinado-Baker, M., Baker, E.W., Phoon, A.C.G. (1989) Mites (Acari) associated with bees (Apidae) in Asia, with description of a new species. Am. Bee J. 129(609-610), 612-613

Hall, T.A. (1999) BioEdit: a user-friendly biological sequence alignment editor and analysis program for Windows 95/98/NT. Nucl. Acids. Symp. Ser. 41, 95-98

Kapil, R.P., Aggarwal, K. (1987) Some observations on the concurrent parasitization of Apis florea by Tropilaelaps clareae and Euvarroa sinhai. Exp. Appl. Acarol. 3, 267-269

Kastberger, G., Raspotnig, G., Biswas, S., Winder, O. (1998) Evidence of Nasonov scenting in colony defence of the Giant honeybee Apis dorsata. Ethology 104, 27-37

Kitprasert C. (1984) Biology and systematics of the parasitic mite, Tropilaelaps clareae Delfinado and Baker (Acarina: Laelapidae), M.S. Thesis, Kasetsart University, Thailand (in Thai).

Koeniger, N., Musaffar, N. (1988) Lifespan of the parasitic honeybee mite, Tropilaelaps clareae, on Apis cerana, dorsata and mellifera. J. Apic. Res. 27, 2017-2212

Koeniger, N., Koeniger, G., Gries, M., Tingek, S., Kelitu, A. (1996) Observations on colony defense of Apis nuluensis and predatory behaviour of the hornet, Vespa multimaculata Pérez, 1910. Apidologie 27, 341-352
Martin, P., Bateson, P. (2007) Measuring behavior: an introductory guide, p. 176. Cambridge University Press, New York

Peng, Y.S., Fang, Y., Xu, S., Ye, L. (1987) The resistance mechanism of the Asian honeybee, Apis cerana Fabr., to an ectoparasitic mite, Varroa jacobsoni Oudemans. J. Invert. Path. 49, 54-60

Radloff, S.E., Hepburn, C., Hepburn, H.R., Fuchs, S., Hadisoesilo, S., Tan, K., Engel, M.S., Kuznetsov, V. (2010) Population structure and classification of Apis cerana. Apidologie 41, 589-601

Rath, W. (1999) Co-adaptation of Apis cerana Fabr. and Varroa jacobsoni Oud. Apidologie 30, 97-110

Rinderer, T.E., Oldroyd, B.P., Lekprayoon, C., Wongsiri, S., Thapa, R. (1994) Extended survival of the parasitic mite Tropilaelaps clareae on adult workers of Apis mellifera and Apis dorsata. J. Apic. Res. 33, 171-174

Ritter, W., Schneider-Ritter, U. (1988) Differences in biology and means of controlling Varroa jacobsoni and Tropilaelalps clareae, two novel parasitic mites of Apis mellifera. In: Needham, G.R., Page Jr., R.E., Delfinado-Baker, M., Bowan, C.E. (eds.) Africanized Honeybees and Bee Mites, pp. 387-395. Halsted, New York

Rosenkranz, P., Fries, I., Boecking, O., Sturner, M. (1997) Damaged Varroa mites in the debris of honeybee (Apis mellifera L.) colonies with and without hatching brood. Apidologie 28, 427-437

Ruttner, F., Hanel, H. (1992) Active defense against Varroa mites in a carniolan strain of honeybee (Apis mellifera carnica Pollman). Apidologie 23, 173-187

Sakagami, S.F. (1960) Preliminary report on the specific differences of behaviour and other ecological characters between European and Japanese honeybees. Acta Hymenopterol. 1, 71-198

SAS Institute (2008) SAS User's Guide, Version 9.2. SAS Institute, Cary

Tan, K., Hepburn, H.R., Radloff, S.E., Yu, Y., Liu, Y., Zhou, D., Neumann, P. (2005) Heat-balling wasps by honeybees. Naturwissenschaften 92, 492-495

Tan, K., Li, H., Yang, M.X., Hepburn, H.R., Radloff, S. E. (2010) Wasp hawking induces endothermic heat production in guard bees. J. Insect Sci. 10, 158

White, T.J., Bruns, T., Lee, S., Taylor, J. (1990) Amplification and direct sequencing of fungal ribosomal RNA genes for phylogenetics. In: Innis, M.A., Gelfand, D.H., Shinsky, J.J., White, T.J. (eds.) PCR Protocols: A Guide to Methods and Applications, pp. 315-322. Academic, San Diego

Wongsiri S., Tangkanasing P., Sylvester H.A. (1989) The resistance behavior of Apis cerana against Tropilaelaps clareae, Proc. First Asia-Pacific Conf. of Enotmol. Chiang Mai, Thailand; pp 828-836.

Woyke, J. (1984) Survival and prophylactic control of Tropilaelaps clareae infesting Apis mellifera colonies in Afghanistan. Apidologie 15, 421-434 